\title{
IMPACT OF LEACHATES ON THE QUALITY OF GROUNDWATER IN SHAGAMU SOUTHWESTERN, NIGERIA IN GROUNDWATER - SOME URBAN CITIES OF \\ SOUTHWESTERN, NIGERIA
}

'Laniyan, Temitope A.; ${ }^{1}$ Bayewu, Olateju 0 and ${ }^{1}$ Mosuro, Ganiyu 0

'Department of Earth Sciences, Olabisi Onabanjo University, Ago-iwoye, Ogun state, Nigeria.

Correspondence Author E-mail: laniyan.temitope@oouagoiwoye.edu.ng

\section{ABSTRACT}

The overwhelming environmental significance of solid waste has attracted a lot of attention because of its leaching into groundwater through waste deposit. The study determines impact of leachate from a landfill site on the quality of groundwater sources in Shagamu, Southwestern, Nigeria. Twelve components. Groundwater qualities for cation were determined at Acme Laboratories Canar ionic anion was determined at the University of Ibadan, Nigeria. Mean concentration of $\mathrm{pH}(5.89)$ was found to be outside the WHO 2004 and USEPA 2001 permissible limits, and was due to the effect of leachate on the groundwater. Total dissolved solid, Electrical conductivity and Alkalinity were found to be within the permissible limits. Mean concentration of cations and anions for all the samples were also found to be within the permissible limits with the exception of Mn $(0.50 \mathrm{mg} / \mathrm{L}), \mathrm{Cl}(83.33 \mathrm{mg} / \mathrm{L})$, and $\mathrm{NO}_{3}(26.44 \mathrm{mg} / \mathrm{L})$ respectively which could be as a result of abattoir found around the dumpsite. Leachate has had significant impact on groundwater quality. Groundwater quality improves with increase in depth and distance of the well and boreholes from the pollution source (landfill). The present study demands for proper management of waste and suggests some remedial measures to

Keywords: Water quality, Ground water, Contamination, Leachate, Landfill.

Accepted Date: 23 May 2018

\section{INTRODUCTION}

A landfill a managed facilities for the disposal of solid waste is a carefully designed structure built into or on top of the ground, in which trash is separated from the area around it (ADS 2017) Landfills are located, designed, operated and monitored to ensure compliance with fed regulations, and are also designed to protect the environment from contaminants, which may be present in the waste strelm. Lar built in environmentally-sensitive areas, and they are placed using on-site environmental monitoring systems (EPA 2016), but due to population increase and indiscriminate dumping of refuse in the environment landfills have been identified as one of the major threats to groundwater resources (Fatta et al. 1999; US EPA, 1984). Waste placed in et al., 1999; US EPA, 1984). Waste placed in landfills or open dums are subjected to eithe precipitation caused by rain. The dumped solid wastes gradually release its initial interstitial water and some of its decomposition by-products get into water moving through the waste deposit, such liquid containing innumerable organic and inorganic compound is called 'leachate.' Leachate is one of the most common types of liquid that can seep into our water supply and contaminate it. Leachate is a liquid that drains or 'leaches' from a landfill. The moisture can come from rain, snow melts or from the waste itself. It varies widely in melts or from the waste itself. It varies widely in composition depending on the age of the landfill contains both dissolved and suspended materials. Leachate varies widely in composition regarding the age of the landfill and the type of waste that it contains. It usually contains both dissolved and cuspended material it accumulates at the bettom of suspended material it accuns botes at the bottom of 2017; IDR 2015). Whon wase is plat (TLE 2017, IDR 2015). When waste is placed in landfills, over time the waste decomposes and sweats. This 
liquid, leachate, is hazardous and must be collected for disposal (IDR, 2015), The leachate from Municipal Solid waste landfills is a highly concentrated "chemical soup", so concentrated that small amounts of leachate can pollute large amounts of groundwater, leaving it unsuitable for domestic water use, unfortunately, this hazardous liquid are left uncollected and they become environmental menace through concentration and toxicity of contaminants, permeability and type of the geologic strata and the direction of groundwater flow. Water flows through an improper disposed groundwater by pronoting and asisting the process of decomposition through bactera the

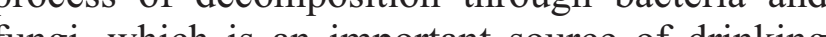
wer which is an important source of drinking water for many rural areas and small communities (Naveen et al., 2016). The process thus release toxic metals into the groundwater thereby polluting the water, such metals are: lead that causes anorexia, abdominal pain, constipation, chronic nephropathy, hypertension; Mercury which causes mors, memory loss, seizures, come, iritability, che kidney filure, decrease in platele, anaemia that follows compou cosole possible prostate and lung problems; Phenols and cresols that causes renal failure and Benzene that causes blood-related disorders(Raihan and Alam 2008).Thus, residents living close to the landfills run the risk of contracting several health problems which could be from an acute/short exposure, or ong term chronic exposure to leachates from landfills, such health problems include profuse disorders, birth defects, even cancer, medical literature tells us. (Kannan 2016, IDR, 2015). The impact of leachate on groundwater has attracted lot of attention because of its overwhelmin environmental significance (Tijani 1994).

The total assessment of the landfill waste of IsaleJagba and the Abattoir in Shagamu, south wester Nigeria, revealed that about $80 \%$ of the total waste is organic in nature, followed by plastic/nylon $15.72 \%$ and $1 \%$ metal (Akinbile and Yusoff 2011) Increasing waste generation and disposal would result in increase groundwater pollution. The extent of contamina to leachate percolation to leachate percolation de factors like leachate composition, rainfall, dept and distance of the well from the pollution source. The extent at which water hand dug wells and boreholes in the area have been contaminated by the landfill site is unknown and hence needed to be determined.

\section{BACKGROUND}

Shagamu, a densely populated and industrialized city (Fig 1.0) with an extent of about 27.4 square kilometers is located within Dahomey Basin, and has a dendritic drainage typical of sedimentary environment with uniform resistance and fairly homogenous geology composed predominantly of a shale clayey sequence of the Akinbo Formation underlain by limestone of the Ewekoro formation The area has a tropical climate and average rainfal of about $230 \mathrm{~mm}$ while temperature ranges from 29 ${ }^{\circ} \mathrm{C}$ during dry season to about $33^{\circ} \mathrm{C}$ in rainy seaso Relative humidity lies between $65 \%$ and $75 \%$, climate.

\section{MATERIALS AND METHOD}

A total of twelve (12) groundwater samples (7 hand-dug wells and 5 boreholes) were analyzed for their major ionic components alongside their physio-chemical parameters. Samples were placed in clean plastic containers after de-ionising the containers, two drops of nitric acid were added into the sample for cation analysis, while samples that were to be used for anion analysis were stored in the refrigerator at $4^{\circ} \mathrm{C}$. Physical parameters $(\mathrm{pH}$, Total dissolved solids, Electrical conductivity, Temperature) were measured in-situ on the field with appropriate standard meters.

Geochemical analysis of the samples was carried out using inductive couple plasma- mass spectrometry and inductive couple plasma-atomic emission spectrometry for cations and trace elements at Acme laboratories, Canada; $\mathrm{HCO}_{3}$ wasdeterminedby titrimetric method, Sulphate $\left(\mathrm{SO}_{4}^{2-}\right)$ was determined by turbidimetric method, phenol disulphonic method was used in the determination of nitrate( $\mathrm{NO}_{3}$ ) while chloride $\mathrm{Cl}$ ) was determined using ion chromatography at the University of Ibadan, Nigeria.

\section{RESULTS AND DISCUSSION}

Physio-Chemical Characteristics of Leachate and Ground water

Mean values of the Electrical conductivity (370.58), temperature and Total Dissolved Solid (108.33) were found to be within the WHO (2010) USEPA (2009) and SON (2007) permite USEPA (2009) and SON (2007) permissible limits with the excepton of pH was found in wells that are close to the dumpsite. High $\mathrm{pH}$ was observed in the dumpsite because of the decomposition process that takes place within the site, and the process led to increase in the temperature and complete decrease in the $\mathrm{pH}$ immediately.

The mean concentrations of the metals $\mathrm{Pb}$ (0.s0365), Zn (0.042), Mn (2.482), Fe (0.0458), K (4.693), $\mathrm{Na}(27.1$ WHO (2010) USEPA (2009) to SON permissible limit while the mean value and range of permissible limit while the mean value and range of the anions 22.14), revealed anthropogenic impact which could become a problem if not controlled. $\mathrm{C}$ showed the impact of sewage effluent on the landfill which is present in water in the form of sodium chloride and gives such water a salty detectable taste. Nitrate $\left(\mathrm{NO}_{3}^{-}\right)$the most highly oxidized form of nitrogen compounds, is commonly present in surface and groundwate because it is the end product of the aerobic decomposition of organic nitrogenous matter. Unpolluted natural waters usually contain only minute quantities of nitrate. The mean value and range of $\mathrm{HCO}^{-}(93.33 \&$ \& 50-270) showed that the metal is a 3 (93.33 \& 50-270) showed the which is also an anthropogenic impact. which is also an (Figh 2 ) of heavy Geochemical maps (Figure 2) of heavy metals revealed a higher concentration of elements near the dumpsite while concentration decreases as distance increases away from the dumpsites.

\section{Statistical Parameter}

\section{Inter-Elemental}

Inter-elemental analysis (Table 2) of metals revealed a strong and positive correlation for $\mathrm{Pb}$ $\mathrm{Cu}, \mathrm{Zn}-\mathrm{Cu}, \mathrm{Cd}-\mathrm{Ba}$ with 'r' values of $0.72,0.58$ and 0.69 respectively which indicates the metals to be governed by the same geochemical factors and are from the same anthropogenic source. A strong and negative correlation was observed between $\mathrm{Cu}-\mathrm{Ba}$ $(' r '=-0.69)$ and $\mathrm{Zn}-\mathrm{Mn}\left(\mathrm{r}^{\prime}=-0.59\right)$ this indicates that the metals are from different geochemical source. Therefore, Ba and $\mathrm{Mn}$ come from the weathering of rocks (geogenic) while $\mathrm{Cu}, \mathrm{Pb}$ and $\mathrm{Zn}$ are positively related and are introduced from leachates.

\section{Piper Trilinear Diagram}

The result of Piper Trilinear diagramis presented in (Fig 3)(Furtak and Langguth (1967) 67\% of the water can be classified as normal alkaline chloride water, $8 \%$ as alkaline carbonate water type with high alkaline proportion, $8 \%$ as calcium carbonate chloride water type and $8 \%$ falls in the calcium carbonate water field.

\section{Ground Water Flow}

Ground water flow as shown in (Figure 4) revealed that water from wells situated close to the landfill are more liable to be contaminated than those farther away due to the gravitational movement of the viscous fluid, With increasing time the viscous 
fluid penetrates deeper and spread all over a longer revealed the flow of ground waters from beneath distance. Elements tend to accumulate from the the dump site to be in the north-western and western north-western while concentration decreas, moving eastward from the dumpsite. Flow net

\begin{tabular}{|c|c|c|c|c|c|}
\hline $\begin{array}{c}\text { Element } \\
\mathrm{pH}\end{array}$ & $\begin{array}{c}\text { Mean } \\
5.89\end{array}$ & $\begin{array}{c}\text { Range } \\
5.1-8.62\end{array}$ & $\begin{array}{c}\text { W.H.O 2010 } \\
6.5-8.5\end{array}$ & $\begin{array}{c}\text { E.P.A 2009 } \\
6.5-8.5\end{array}$ & $\begin{array}{c}\text { S.O.N } 2007 \\
6.5-8.5\end{array}$ \\
\hline Alkalinity & 27.5 & $0-140$ & - & - & - \\
\hline TDS & 108.33 & $0-206$ & 500 & 500 & 500 \\
\hline Conductivity & 370.58 & $109-956$ & 1400 & 1400 & 1000 \\
\hline $\mathrm{Pb}$ & 0.00365 & 0.0004- 0.0119 & 0.01 & 0.015 & 0.01 \\
\hline $\mathrm{Zn}$ & 0.042 & $0.0123-0.082$ & 3 & 5 & 3 \\
\hline $\mathrm{Fe}$ & 0.0458 & $0.010-0.109$ & $0.5-50$ & 0.3 & 0.3 \\
\hline $\mathrm{Ca}$ & 17.64 & $0.68-108.71$ & 200 & 75 & 75 \\
\hline $\mathrm{Cd}$ & 0.0002 & $0.00009-0.0005$ & 0.003 & 0.005 & - \\
\hline $\mathrm{Cu}$ & 0.0131 & $0.0008-0.0406$ & 2.0 & 1.300 & 1.0 \\
\hline As & 0.0005 & $0.0001-0.0005$ & 0.01 & 0.05 & 0.01 \\
\hline $\mathrm{Mn}^{+}$ & 2.482 & $0.22-5.59$ & 50 & 50 & 0.2 \\
\hline $\mathrm{Na}^{+}$ & 27.15 & 2.34- 69.90 & 200 & 200 & 200 \\
\hline $\mathrm{K}^{+}$ & 4.693 & $0.51-15.21$ & 13.48 & 12 & \\
\hline $\mathrm{HCO}_{3}^{-}$ & 93.33 & $50-270$ & 250 & - & - \\
\hline $\mathrm{Cl}^{-}$ & 83.33 & $50-180$ & 250 & 600 & 250 \\
\hline $\mathrm{SO}_{4}{ }^{2-}$ & 15.42 & $6.98-22.14$ & 250 & 250 & 100 \\
\hline $\mathrm{NO}_{3}^{-}$ & 26.44 & $16.11-44.2$ & 50 & 25 & 50 \\
\hline
\end{tabular}

TDS = Total Dissolved Solids, $\mathrm{mg} / \mathrm{l}$,

$\mathrm{EC}=$ Electrical Conductivity $(\mu \mathrm{s} / \mathrm{cm})$

Gî - World Health Organization,

Erotection Authority

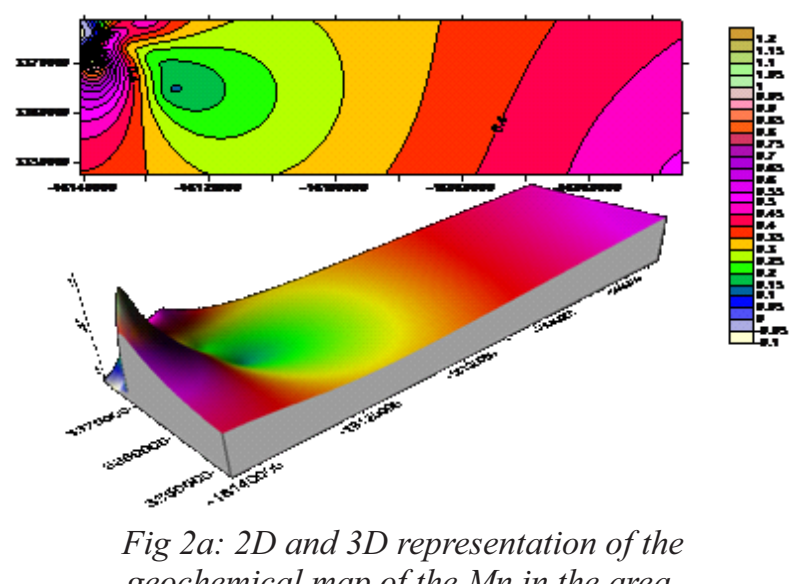

Fig 2a. 2 Dand 3 Drepresentation of the
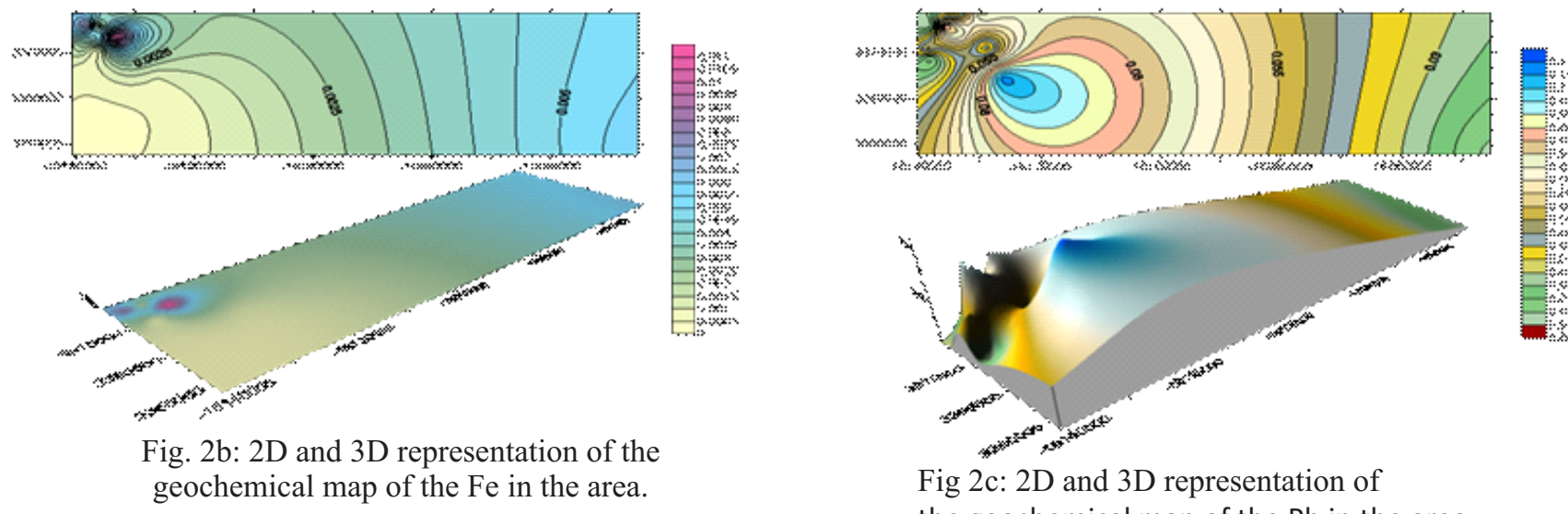

the geochemical map of the $\mathrm{Pb}$ in the area

Fig 2: Geochemical maps of some heavy metals In the study area

\begin{tabular}{|c|c|c|c|c|c|c|c|}
\hline & $\mathrm{Ba}$ & $\mathrm{Cd}$ & $\mathrm{Cu}$ & $\mathrm{Fe}$ & $\mathrm{Mn}$ & $\begin{array}{l}\mathbf{P b} \\
\end{array}$ & $\mathrm{Zn}$ \\
\hline $\mathrm{Ba}$ & 1 & & & & & & \\
\hline $\mathrm{Cd}$ & 0.69 & 1 & & & & & \\
\hline $\mathrm{Cu}$ & -0.78 & -0.06 & 1 & & & & \\
\hline $\mathrm{Fe}$ & 0.49 & 0.44 & -0.22 & 1 & & & \\
\hline Mn & 0.43 & 0.03 & -0.37 & 0.23 & 1 & & \\
\hline $\mathbf{P b}$ & 0.14 & 0.289 & 0.72 & 0.07 & -0.33 & 1 & \\
\hline $\mathrm{Zn}$ & -0.23 & -0.09 & 0.58 & -0.44 & -0.59 & 0.47 & 1 \\
\hline
\end{tabular}




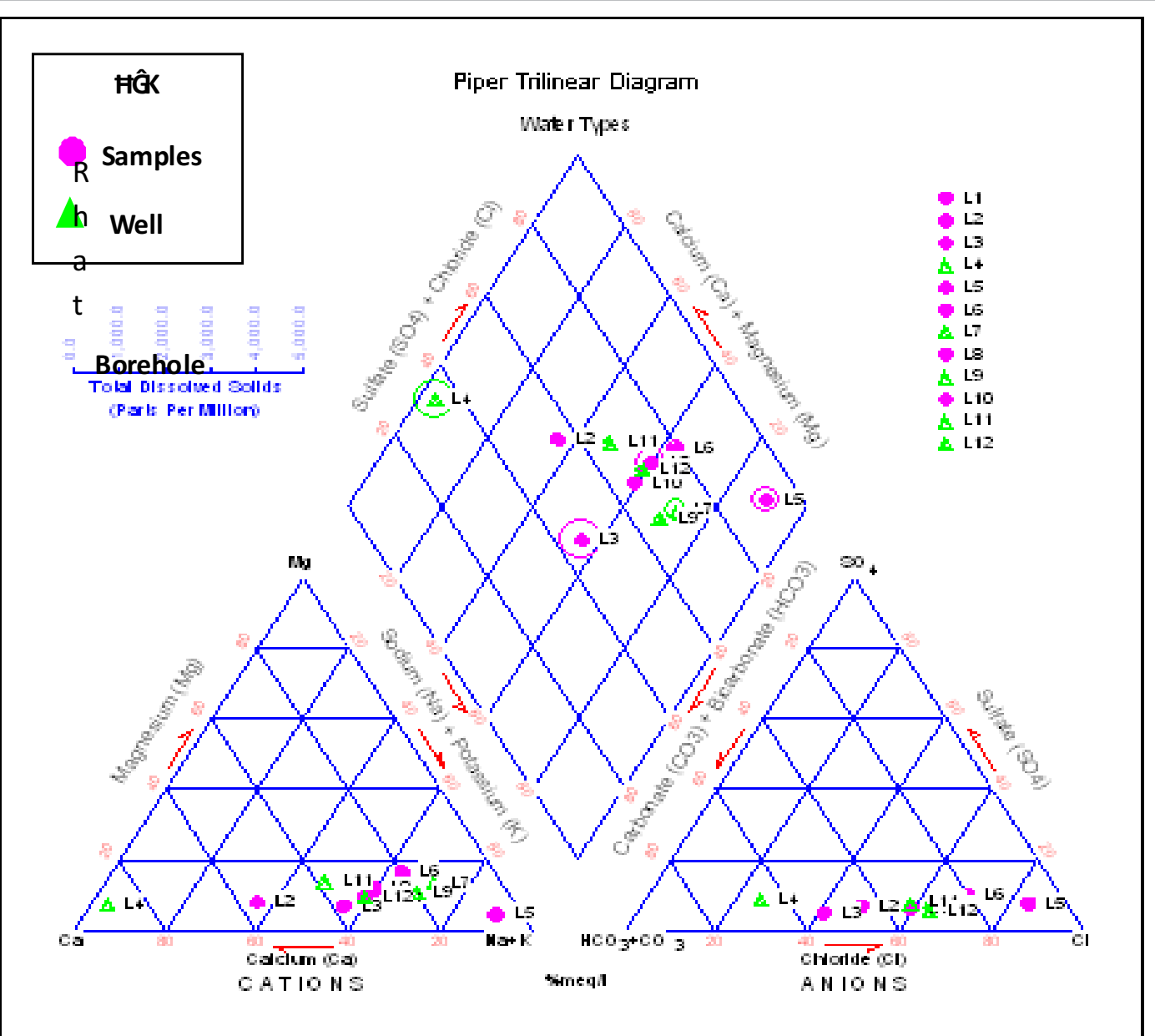

Fig 3:Piper - Trilinear diagram of the study area

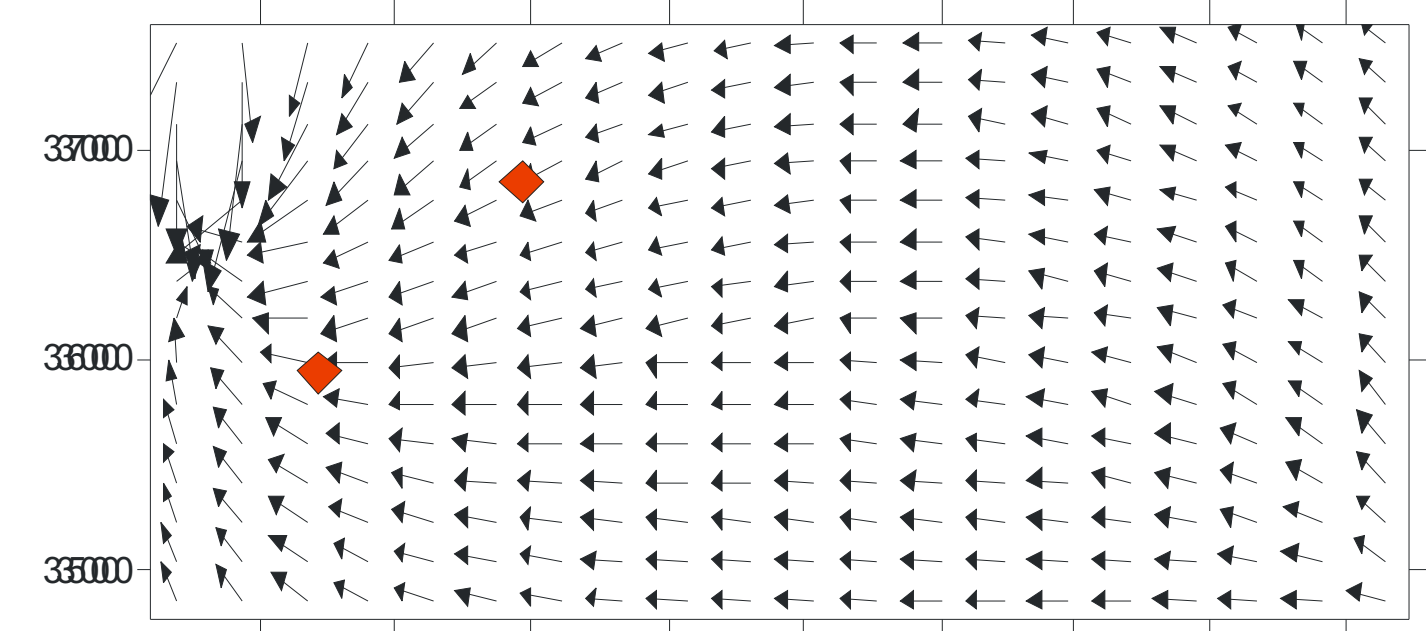

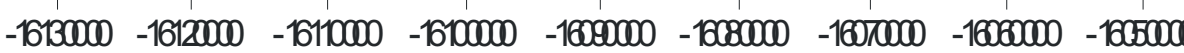

$$
\triangle \text { DUMP SITE KEY FLOW DIRECTION }
$$

Fig 4: Ground water flow of the study area

\section{CONCLUSION}

Leachate had significant impact on the groundwater quality; it was also revealed that groundwater quality improves as the distance to dumpsite landfill increases. A proper management of waste such as provision of impermeable clay covers to limit the infiltration of water through the landfill, thus, reducing the amount of leachate reaching the landfill base; recycling of the

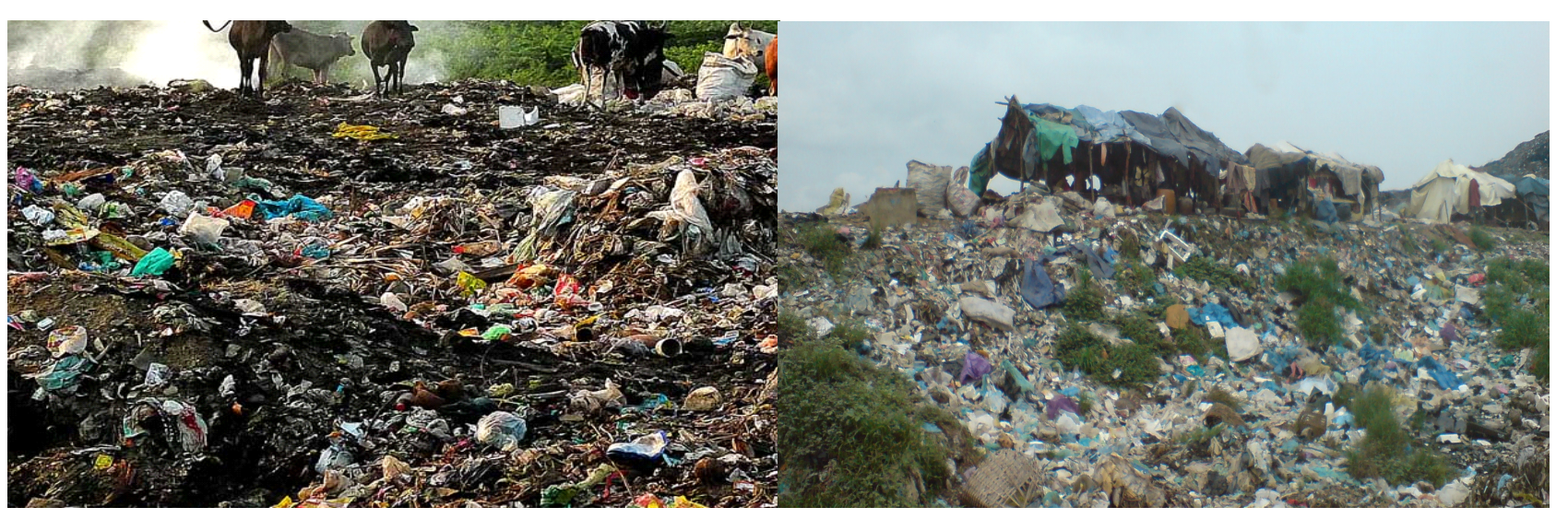

The landfill

The abattoir landfill

\section{REFERENCES}

ADS 2017; Advanced Disposal Services, Inc. In: www.advanceddisposal.com/news/2017. aspx;https://www.bloomberg.com/researc $\mathrm{h} /$ stocks/private/snapshot.asp?privcapId.

BILLMAN, H. G., 1976: Offshore Stratigraphy and Paleontology of the Dahomey Embayment, West Africa. Proc. 7th African Micropaleontology Colloquim

Canter, L.W., 1987: Groundwater Quality Protection. Lewis Publication, Inc, Chelsea, MI.

Akinbile, Christopher O. and Yusoff, Mohd S. 2011: Environmental Impact of Leachate Pollution on Groundwater Supplies in Akure, Nigeria. International Journal of Environmental Science and Development, 2:1, February 2011

Ellis, J. A.: 1980: 'Convenient parameter for tracing leachate from sanitary landfills', Water Res. 14, pp1283-1287. International Journal of Environmental Science and Development. 2:1, February 2011

Fatta D, Papadopoulos, A, and Loizidou, $M$ 1999:'A study on the landfill leachate and its impact on the groundwater quality of the greater area', Environ. Geochem. Health 21(2):175-190.

Furtak, H. and Langguth, H.R. 1967: Zur hydrochemichen Kennzeichnung von Grrunfwassern und Grundwassert penmituls Kennzahien. International. Association of Hydrologist, Manioir 7:8996. Hannover.

IDR, 2015: IDR Environmental Services. Blog, idrenvironmental.com

Kannan Ramya, 2016: What contaminated ground water can do to your health CLEAN CHENNAI Chennai . The Hindu. Chennai August 14, 2013 08:47 IST, Updated: June 02, 2016 03:55 IST

Lloyd, J. W and Heathcote, J.A. 1985: Natural inorganic hydrochemistry in relation to groundwater, Clarendon, Oxford, NewYork. 296 pp.

Loizidou, M. and Kapetanios, E. 1993:'Effect of 
leachate from landfills on underground water quality', Sci. Total Environ. 128, 69-81.

Naveen, B.P., Mahapatra, D.M., Sitharam, T.G., Sivapullaiah, P.V., Ramachandra, T.V., 2016:Physico-chemical and biological characterization of urban municipal landfill leachate. Environmental Pollution, leachate. Environmental Pollution, http://dx.doi.org/10.1016/j.envpol.2016.09

Piper, A.M. 1944: A graphical procedure in geological interpretation of water analysis. Trans American Geophysics Union 25, pp 44-48.

Raihan F and Alam J.B. 2008: Assessment of groundwater quality in sunamganj of Bangladesh. Iran J Environ health Sci and Eng. 5 (3): 155-166.

Standards Organization of Nigeria (2007): Nigeria standard for drinking water quality, ICS 13.060.20: Nigeria Industrial Standard Manual, NIS 554: 2007.

TLE 2017: The Leachate Expert Website. Leachate.co.uk

Tijani, M.N 1994: Hydrogeochemical assessment of groundwater of Moro area, Kwara State, Nigeria Environmental Geology, 24:194 202.

United States Environmental Protection Agency (US EPA) 2009: Office of Drinking Water, Water Protection Strategy for the Environmental Protection Agency, pp. 11. https://www.epa.gov/

World Health Organisation 2010: International Drinking Water Standards. Publications of the World Health Organization can be obtained from WHO Press, World Health Organization, 20 Avenue Appia, 1211 Geneva 27, Switzerland (tel.: +41 22791 3264; fax: +41 22791 4857; e-mail: bookorders@who.int). Requests for permission to reproduce or translate WHO publications - whether for sale or for publications - whether for sale or for
noncommercial distribution - should be addressed to WHO Press, at the above address (fax: +41 22791 4806; e-mail: permissions@who.int). 